\title{
Tumor Necrosis Factor- $\alpha$ Production to Lipopolysaccharide Stimulation by Donor Cells Predicts the Severity of Experimental Acute Graft-Versus-Host Disease
}

\author{
Kenneth R. Cooke, ${ }^{\star}$ Geoffrey R. Hill, ${ }^{\star}$ James M. Crawford, ${ }^{\ddagger}$ David Bungard, ${ }^{\star}$ Yani S. Brinson, ${ }^{\star}$ John Delmonte, Jr., ${ }^{\star}$ \\ and James L.M. Ferrara* \\ *Department of Pediatric Oncology Dana-Farber Cancer Institute, Children's Hospital, and Harvard Medical School, Boston, \\ Massachusetts 02115 and the ${ }^{\ddagger}$ Department of Pathology, Yale University School of Medicine, New Haven, Connecticut 06520-8023
}

\begin{abstract}
Donor $\mathrm{T}$ cell responses to host alloantigen are known predictors for graft-versus-host disease (GVHD); however, the effect of donor responsiveness to an inflammatory stimulus such as lipopolysaccharide (LPS) on GVHD severity has not been investigated. To examine this, we used mouse strains that differ in their sensitivity to LPS as donors in an experimental bone marrow transplant (BMT) system. Lethally irradiated $(\mathrm{C} 3 \mathrm{FeB} 6) \mathrm{F} 1$ hosts received BMT from either LPSsensitive (LPS-s) C3Heb/Fej, or LPS-resistant (LPS-r) C3H/ Hej donors. Mice receiving LPS-r BMT developed significantly less GVHD as measured by mortality and clinical score compared with recipients of LPS-s BMT, a finding that was associated with significant decreases in intestinal histopathology and serum LPS and TNF- $\alpha$ levels. When donor $T$ cell responses to host antigens were measured, no differences in proliferation, serum IFN- $\gamma$ levels, splenic $T$ cell expansion, or CTL activity were observed after LPS-r or LPS-s BMT. Systemic neutralization of TNF- $\alpha$ from day -2 to +6 resulted in decreased intestinal pathology, and serum LPS levels and increased survival after BMT compared with control mice receiving Ig. We conclude that donor resistance to endotoxin reduces the development of acute GVHD by attenuating early intestinal damage mediated by TNF $\alpha$. These data suggest that the responsiveness of donor accessory cells to LPS may be an important risk factor for acute GVHD severity independent of T cell responses to host antigens. (J. Clin. Invest. 1998. 102:1882-1891.) Key words: bone marrow transplantation - T cells - cytokines - gastrointestinal damage $\cdot$ murine
\end{abstract}

\section{Introduction}

During the last several decades, allogeneic bone marrow transplantation $(\mathrm{BMT})^{1}$ has emerged as an important therapy for a number of malignant and nonmalignant diseases. Unfortu-

Address correspondence to Kenneth R. Cooke, M.D., Dana-Farber Cancer Institute, Department of Pediatric Oncology, 44 Binney Street, Boston, MA 02115. Phone: 617-632-5792; FAX: 617-632-2085; E-mail: kenneth_cooke@dfci.harvard.edu J.L.M. Ferrara's current address is Departments of Internal Medicine and Pediatrics, Division of Hematology and Oncology, University of Michigan, Ann Arbor, MI 48109-0560.

Received for publication 15 June 1998 and accepted in revised form 21 September 1998.

J. Clin. Invest.

(C) The American Society for Clinical Investigation, Inc. 0021-9738/98/11/1882/10 \$2.00

Volume 102, Number 10, November 1998, 1882-1891

http://www.jci.org nately, the utility of allogeneic BMT is limited by several serious side effects, the most common of which is graft-versus-host disease (GVHD). The pathophysiology of acute GVHD is complex and is believed to involve donor $\mathrm{T}$ cell responses to host antigens, inflammatory cytokine effectors (such as TNF- $\alpha$ and IL-1), and endotoxin (1). Endotoxin or LPS is a component of endogenous bowel flora and is a potent enhancer of inflammatory cytokine release $(2,3)$. Translocation of LPS across a damaged gut mucosa provides access to the systemic circulation where LPS triggers monocytes and macrophages primed by the effects of IFN- $\gamma$ to release cytopathic amounts of inflammatory cytokines (4). Together with natural killer (NK) and T cells, these cytokines mediate GVHD target organ damage (5-8). Recently, we have shown that acute GVHD severity is enhanced after allogeneic BMT by increasing the intensity of total body irradiation conditioning and that this effect was independent of histocompatibility differences between donor and host (9). GVHD as measured by survival and clinical score was associated with elevated serum levels of both TNF- $\alpha$ and LPS on day 7 after BMT (9).

In light of the critical role of LPS in the inflammatory cascade of GVHD, we investigated the effect of donor responsiveness to LPS on the development of acute GVHD by using mice known to be sensitive or resistant to the effects of LPS as bone marrow donors. $\mathrm{C} 3 \mathrm{H} / \mathrm{Hej}$ and $\mathrm{C} 3 \mathrm{Heb} / \mathrm{Fej}$ are closely related substrains of mice, which differ in their response to the lethal effects of LPS (10). C3Heb/Fej animals exhibit normal murine sensitivity to LPS challenge, whereas a genetic mutation in $\mathrm{C} 3 \mathrm{H} / \mathrm{Hej}$ mice has made this strain resistant to LPS. Although the mechanism of resistance in these mice remains unresolved, it is thought to involve a genetic mutation within the LPS response gene located on chromosome 4 leading either to a defect in signaling or a defect in endocytic uptake of LPS (11-13). At a cellular level, resistance to LPS involves macrophages and mononuclear cells both of which exhibit decreased cytotoxicity and decreased cytokine production when stimulated with LPS (14). LPS-induced T cell activation is also absent in LPS-resistant (LPS-r) mice, a defect that can be overcome by the presence of LPS responsive antigen presenting cells (15). These defects are specific to LPS because macrophages and B cells can respond to other stimuli and importantly, T cells from LPS-r mice respond normally to mitogen $(16,17)$. Use of these mouse strains as BMT donors thus provided an opportunity to study the effects of donor responsiveness to LPS on acute GVHD while keeping the T cell response to host antigen constant. Using an irradiated parent $(\mathrm{P}) \rightarrow \mathrm{F} 1$ hybrid murine BMT model of GVHD, we demonstrate that

1. Abbreviations used in this paper: $\mathrm{BM}$, bone marrow; BMT, bone marrow transplantation; GI, gastrointestinal; GVHD, graft-versushost-disease; LAL, Limulus Amebocyte Lysate; LPS-r, LPS-resistant; LPS-s, LPS-sensitive; PE, phycoerythrin; TCD, T cell-depleted. 
donor responsiveness to LPS is a risk factor of GVHD; resistance to LPS reduces the severity of acute GVHD by attenuating intestinal damage mediated by TNF- $\alpha$.

\section{Methods}

Mice. Female C3H/Hej $\left(\mathrm{H}-2^{\mathrm{k}}\right)$, C3Heb/Fej $\left(\mathrm{H}-2^{\mathrm{k}}\right)$, and $(\mathrm{C} 3 \mathrm{FeB} 6) \mathrm{F} 1$ $\left(\mathrm{H}-2^{\mathrm{kxb}}\right)$ mice were purchased from the Jackson Laboratories (Bar Harbor, ME) and were used for BMT and in vitro experiments between the ages of 12 and $20 \mathrm{wk}$. The $\mathrm{C} 3 \mathrm{H} / \mathrm{Hej}$ and $\mathrm{C} 3 \mathrm{Heb} / \mathrm{Fej}$ substrains have a common origin. $\mathrm{C} 3 \mathrm{Heb} / \mathrm{Fej}$ is a result of a transfer of $\mathrm{C} 3 \mathrm{H} / \mathrm{HeJ}$ ova to $\mathrm{C} 57 \mathrm{BL} / 6(\mathrm{eB})$ performed by Dr. Fekete $(\mathrm{Fe})$ at The Jackson Laboratory in 1948. Despite their separation of $50 \mathrm{yr}$, the mice have very few differences at the DNA level. Histocompatibility between these substrains has been confirmed by the absence of rejection during skin grafting experiments (J. Sharp, manuscript in preparation).

Bone marrow transplantation. Mice were transplanted according to a standard protocol as described previously $(9,18)$. Bone marrow (BM) was harvested from the femurs and tibias of donor mice and depleted of T cells by using an anti-Thy 1.2 MoAb (American Type Culture Collection, Rockville, MD) and Low-Tox-M rabbit complement (Accurate Corp., Westbury, NY). We have previously shown that T cell depletion with two rounds of anti-Thy $1.2 \mathrm{MoAb}$ and complement leaves $<1$ in $10^{4}$ mitogen-responsive $\mathrm{T}$ cells in the BM by limiting dilution assay (19). Cell mixtures of $5 \times 10^{6} \mathrm{~T}$ cell-depleted (TCD) BM cells supplemented with either $1 \times 10^{6}$ or $0.25 \times 10^{6}$ nylon wool nonadherent splenic $\mathrm{T}$ cells from either syngeneic [(C3FeB6)F1] or allogeneic $(\mathrm{C} 3 \mathrm{H} / \mathrm{Hej} / \mathrm{C} 3 \mathrm{Heb} / \mathrm{Fej})$ donors were resuspended in Leibovitz's L-15 medium (Life Technologies, Grand Island, NY) and transplanted into $(\mathrm{C} 3 \mathrm{FeB} 6) \mathrm{F} 1$ recipients via tail vein infusion $(0.25 \mathrm{ml}$ total volume). Consistent with previous results, 70 $75 \%$ of cells obtained after nylon wool passage were positive for CD4 or CD8 surface antigens. In some experiments, (C3FeB6)F1 animals received $\mathrm{TCD} \mathrm{BM}$ only from $\mathrm{C} 3 \mathrm{Heb} / \mathrm{Fej}$ donors. Before transplant, host mice received 11 Gy of total body irradiation $\left({ }^{137} \mathrm{Cs}\right.$ source $)$ delivered in two fractions separated by $3 \mathrm{~h}$ to reduce gastrointestinal toxicity. Mice were subsequently housed in sterilized microisolator cages and received normal chow and autoclaved hyperchlorinated water for the first $2 \mathrm{wk}$ after BMT and filtered water thereafter.

Systemic and histopathologic analysis of GVHD. The degree of systemic GVHD was assessed by a standard scoring system that incorporates five clinical parameters: weight loss, posture (hunching), activity, fur texture, and skin integrity $(9,20)$. Transplanted mice were ear punched, and individual weights were obtained and recorded on day 0 and weekly thereafter. At the time of analysis, mice from coded cages were evaluated and graded from 0 to 2 for each criterion. A clinical index was subsequently generated by summation of the five criteria scores (maximum index $=10$ ). We have found this index to be a more sensitive index of GVHD severity than weight loss alone, a parameter that has been found to be a reliable indicator of systemic GVHD in multiple murine models (21-23).

Acute GVHD was also assessed by detailed histopathologic analysis of liver and intestine, two primary GVHD target organs. Small bowel (distal), large bowel (transverse), and liver (right lobe) were harvested from animals day 6 after BMT and placed in buffered formalin. Specimens were then embedded in paraffin, cut into 5- $\mu \mathrm{m}$ thick sections, and stained with hematoxylin and eosin for histological examination. Slides were coded without reference to mouse type or prior treatment status and examined systematically by a single pathologist (J.M.C.) using a semiquantitative scoring system for abnormalities known to be associated with $\operatorname{GVHD}(24,25)$. Specific parameters scored included villous blunting, crypt regeneration, crypt epithelial cell apoptosis, crypt loss, luminal sloughing of cellular debris, lamina propria inflammatory cell infiltrate, and mucosal ulceration in the small bowel, crypt regeneration, crypt epithelial cell apoptosis, crypt loss, surface colonocyte vacuolization, surface colonocyte attenuation, lamina propria inflammatory cell infiltrate, and mucosal ulceration in the large bowel and portal tract expansion by an inflammatory cell infiltrate, lymphocytic infiltrate of bile ducts, bile duct epithelial cell apoptosis, bile duct epithelial cell sloughing, vascular endotheliitis, parenchymal apoptosis, parenchymal microabscesses, parenchymal mitotic figures, hepatocellular cholestasis, and hepatocellular steatosis in the liver. The scoring system for each parameter that evaluated both the extent and severity of tissue damage denoted 0 as normal, 0.5 as focal and rare, 1 as focal and mild, 2 as diffuse and mild, 3 as diffuse and moderate, and 4 as diffuse and severe. The criteria for mild, moderate, and severe damage for these parameters are as previously published for histological studies of human acute $\operatorname{GVHD}(26,27)$ and as reported previously by our laboratory $(9,28)$. Scores were subsequently added to provide a total score for each specimen.

Cell culture, analysis of proliferative response, and cytokine production. All culture media reagents were purchased from Gibco BRL (Gaithersburg, MD). For analysis of proliferative response and IFN- $\gamma$ production, splenocytes were harvested from transplanted mice on day 6 after BMT and pooled within treatment groups $(n=$ 3-4 animals per group). Cells were suspended in 5\% FCS/RPMI supplemented with $50 \mathrm{U} / \mathrm{ml}$ penicillin, $50 \mu \mathrm{g} / \mathrm{ml}$ streptomycin, $2 \mathrm{mM}$ L-glutamine, $1 \mathrm{mM}$ sodium pyruvate, $0.1 \mathrm{mM}$ nonessential amino acid, $0.02 \mathrm{mM} \beta$-mercaptoethanol, and $10 \mathrm{mM}$ HEPES ( $\mathrm{pH} 7.75$ ). These cells $\left(0.5 \times 10^{5}\right.$ to $\left.2 \times 10^{5}\right)$ were cultured in flat-bottomed 96-well Falcon plates (Lincoln Park, NJ) in the presence of irradiated (2,000 Rad) peritoneal cells lavaged from naive (C3FeB6)F1 (host) animals at $37^{\circ} \mathrm{C}$ in a humidified incubator supplemented with $5 \%$ $\mathrm{CO}_{2}$. Supernatants were collected at $48 \mathrm{~h}$ for IFN- $\gamma$ analysis by ELISA, and proliferative response to host antigen was measured by a 1205 Betaplate reader (Wallac, Turku, Finland) after $72 \mathrm{~h}$ by incorporation of $\left[{ }^{3} \mathrm{H}\right]$ thymidine $(1 \mu \mathrm{Ci})$ for the last $24 \mathrm{~h}$ of incubation. In additional experiments, nylon wool purified $\mathrm{T}$ cells were harvested from naive BMT donors and stimulated with host $(\mathrm{C} 3 \mathrm{FeB} 6) \mathrm{F} 1$ antigens or Concanavalin A $(2.5 \mu \mathrm{g} / \mathrm{ml})$ and analyzed for proliferative response and IFN- $\gamma$ production as above.

For studies of TNF- $\alpha$ secretion, naive peritoneal cells or splenocytes from transplanted mice $6 \mathrm{~d}$ after BMT were suspended in $5 \%$ FCS RPMI supplemented as above and plated at $2 \times 10^{5}$ (peritoneal cells) or $4 \times 10^{5}$ (splenocytes) cells per well in flat-bottomed 96-well Falcon plates with varying concentrations of LPS. Cell culture was performed at $37^{\circ} \mathrm{C}$ in a humidified incubator supplemented with $5 \%$ $\mathrm{CO}_{2}$. Supernatants were collected after $4 \mathrm{~h}$ of culture for TNF- $\alpha$ analysis by ELISA.

${ }^{51}$ Cr release assays. $2 \times 10^{6} \mathrm{P} 815\left(\mathrm{H}-2^{\mathrm{d}}\right)$ or EL4 $\left(\mathrm{H}-2^{\mathrm{b}}\right)$ tumor targets were labeled with $100 \mu \mathrm{Cu}$ of ${ }^{51} \mathrm{Cr}$ for $2 \mathrm{~h}$. After washing three times, labeled targets were plated at $10^{4}$ cells per well in U-bottom plates (Costar, Cambridge, MA). Allogeneic splenocyte preparations as described above were added to quadruplicate wells at varying effector $\left(\mathrm{CD}^{+}\right.$plus $\left.\mathrm{CD}^{+}\right)$to target ratios and incubated as above. Maximal and background release was determined by the addition of Triton-X (Sigma Chemical Co., St. Louis, MO) or media alone to targets, respectively. ${ }^{51} \mathrm{Cr}$ activity in supernatants taken $5 \mathrm{~h}$ later were determined in a Cobra auto-gamma counter (Meriden, CT), and lysis was expressed as a percentage of maximum.

Cell surface phenotype analysis. To analyze cell surface phenotype, splenocytes and peritoneal cells from transplanted mice were resuspended in PBS and stained with FITC-conjugated MoAbs to CD4 (PharMingen, San Diego, CA) and F4/80 (Caltag Laboratories, San Francisco, CA) or phycoerythrin (PE)-conjugated CD8 (PharMingen, San Diego, CA) for flow cytometric analysis. Cells $\left(0.5 \times 10^{6}\right)$ were incubated for $20 \mathrm{~min}$ at $4^{\circ} \mathrm{C}$ with $\mathrm{MoAb} 2.4 \mathrm{G} 2$ to block nonspecific staining via $\mathrm{Fc}$ receptors and then with the appropriate FITC- or PE-conjugated MoAbs for $30 \mathrm{~min}$ at $4{ }^{\circ} \mathrm{C}$. The cells were subsequently washed twice with PBS $0.2 \%$ BSA before fixation in $1 \%$ paraformaldehyde. Two-color flow cytometric analysis of $10^{4}$ cells was performed using a FACScan (Becton Dickinson, Mountain View, CA). The FACScan was calibrated using PE- and FITC-conjugated, nonspecific IgG antibodies. 
Cytokine ELISA. Concentrations of TNF- $\alpha$ and IFN- $\gamma$ were measured in serum and cell culture supernatants by sandwich ELISA by using specific anti-murine MoAbs for capture and detection and the appropriate standards: IFN- $\gamma$ (PharMingen) and TNF- $\alpha$ (Genzyme, Cambridge, MA). Assays were performed according to the manufacturer's protocol. Samples were diluted 1:2 to 1:5, and samples and standards were run in duplicate. The sensitivity of the assays was $16-20 \mathrm{pg} / \mathrm{ml}$ for TNF- $\alpha$ and $0.25 \mathrm{U} / \mathrm{ml}$ for IFN- $\gamma$. ELISA plates were read at $450 \mathrm{~nm}$ by using a microplate reader (Bio-Rad Labs, Hercules, CA).

Serum LPS determination. For determination of endotoxin concentration in serum, the Limulus Amebocyte Lysate (LAL) assay (Bio Whittaker, Walkersville, MD) was performed according to the manufacturer's protocol as previously described $(9,20)$. In brief, serum samples were collected and analyzed using pyrogen-free materials, diluted $10 \%$ (vol/vol) in LAL reagent water and heated to $70^{\circ} \mathrm{C}$ for $5 \mathrm{~min}$ to remove any nonspecific inhibition to the assay. Samples were then incubated with equal volumes of LAL for $10 \mathrm{~min}$ at $37^{\circ} \mathrm{C}$ and developed with equal volumes of substrate solution for $6 \mathrm{~min}$. The absorbance of the assay plate was read at $405 \mathrm{~nm}$ by using the same microplate reader used in cytokine assays. Samples and standards were run in duplicate and the lower limit of detection was 0.15 $\mathrm{U} / \mathrm{ml}$. All units expressed are relative to the U.S. reference standard EC-6.

rhTNFR:Fc treatment. Recombinant human TNF receptor bound to the Fc portion of human immunoglobulin (rhTNFR:Fc) was supplied by Immunex (Seattle, WA) (29). Mice were injected intraperitoneally with $100 \mu \mathrm{g}$ of rhTNFR:Fc on days $-2,-1,0,+1,+2$ then alternate days up to and including day 6 (seven injections total). As recommended by the manufacturer, rhTNFR:Fc was diluted in normal saline before injection. Mice from the control group received 100 $\mu \mathrm{g}$ of human IgG similarly diluted.

Statistical considerations. All values are expressed as the mean \pm SEM. Statistical comparisons between groups were completed using the nonparametric, unpaired, Mann-Whitney Test, except for analyzing survival data when the Wilcoxon rank-test was used. $P<0.05$ is considered statistically significant.

\section{Results}

Macrophages from naive C3H/Hej mice are resistant to LPS stimulation, but $T$ cells respond normally to mitogen and alloantigens. To determine the effects of donor responsiveness to LPS on acute GVHD severity, we first measured TNF- $\alpha$ production by naive macrophages from either $\mathrm{C} 3 \mathrm{H} / \mathrm{Hej}$ or $\mathrm{C} 3 \mathrm{Heb} / \mathrm{Fej} \mathrm{BMT}$ donors to LPS stimulation in vitro. Peritoneal macrophages were harvested from LPS-resistant (LPS-r) $(\mathrm{C} 3 \mathrm{H} / \mathrm{Hej})$ and LPS-sensitive (LPS-s) $(\mathrm{C} 3 \mathrm{Heb} / \mathrm{Fej})$ mice and cultured in the presence of increasing concentrations of LPS as described in Methods. FACS analysis demonstrated that $33 \%$ of cells in each group were positive for the macrophage cell surface marker F4/80. After 4 h, cell culture supernatants were harvested and subsequently analyzed for TNF- $\alpha$ by ELISA. As shown in Fig. $1 A$, cells from LPS-s demonstrated normal responsiveness and produced significant amounts of TNF- $\alpha$ after LPS stimulation. By contrast, cells from LPS-r produced little or no TNF- $\alpha$, consistent with the LPS-resistant phenotype of this mouse strain. Similar findings were seen after LPS stimulation of bone marrow cells from animals in each group (data not shown). We next investigated the ability of naive $\mathrm{T}$ cells from LPS-s and LPS-r animals to respond to Concanavalin A, and alloantigens present on (C3FeB6)F1 stimulator cells. As shown in Fig. $1 B$, the proliferative responses of nylon wool nonadherent splenic $\mathrm{T}$ cells from both LPS-s and LPS-r animals were equivalent, and LPS-r T cells were capable of pro-
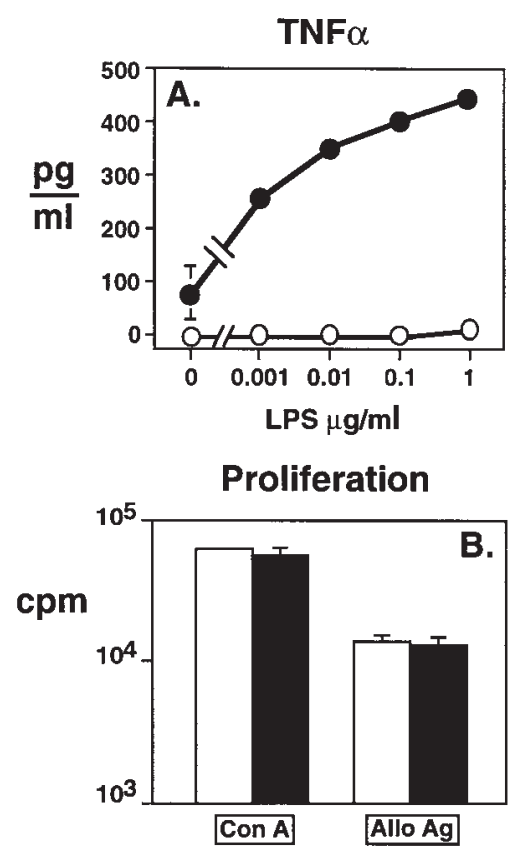

Figure 1. Peritoneal macrophage $(A)$ and $\mathrm{T}$ cell ( $B$ and $C$ ) responses from naive LPS-s (filled circles) and LPS-r (open circles) BMT donor mice. (A) Peritoneal macrophage TNF- $\alpha$ production to LPS stimulation in vitro. Peritoneal cells were harvested from naive animals (two to three per group), pooled, and cultured with increasing concentrations of LPS as described in Methods. TNF- $\alpha$ production was measured by ELISA. Data are expressed as mean \pm SEM of triplicate wells and represent one of two similar experiments. Values were standard-

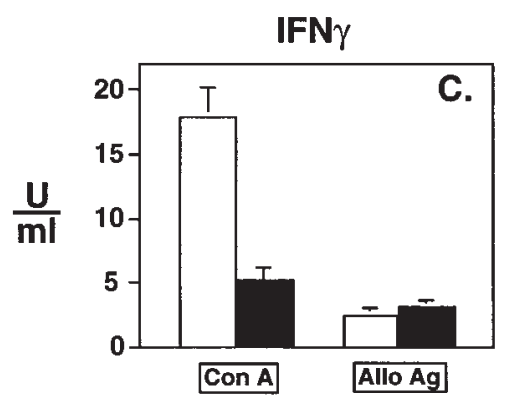
ized for percent macrophages present in each group as determined by FACS analysis using F4/80 positivity. Proliferation $(B)$ and IFN- $\gamma$ production (C) of naive splenic T cells from LPS-s (filled bars) and LPS-r (open bars) mice to mitogen (Con A) and host [(C3FeB6)F1] antigens in vitro. Nylon wool purified splenic T cells were harvested from naive animals (two per group), pooled, and cultured $\left(200 \times 10^{3}\right.$ responders per well) with Con A or irradiated host stimulator cells as described in Methods. Values for proliferation and IFN- $\gamma$ production were normalized for the percent CD4 and CD8 positive T cells present in each group as determined by FACS analysis. Data are expressed as mean \pm SEM of quadruplicate wells and represent one of two similar experiments.

ducing equal or greater amounts of IFN- $\gamma$ compared with that secreted by LPS-s T cells (Fig. $1 C$ ).

Transplantation of LPS-resistant donor cells leads to decreased TNF- $\alpha$ production after allogeneic BMT. Use of LPS- $r$ and LPS-s mice as BMT donors provided an opportunity to evaluate the effects on donor responsiveness to LPS on acute GVHD while keeping donor $\mathrm{T}$ cell responses to host antigens constant. Lethally irradiated (C3FeB6)F1 mice received TCD $\mathrm{BM}$ and $1 \times 10^{6} \mathrm{~T}$ cells from either allogeneic LPS-r or LPS-s donors as described in Methods. In initial experiments, recipients of TCD LPS-s BM only served as negative GVHD controls. Given the difference in naive donor cell response to LPS, we first analyzed TNF- $\alpha$ production $6 \mathrm{~d}$ after BMT. Splenocytes were harvested from BMT recipients and cultured in vitro with increasing concentrations of LPS as described in Methods. As shown in Fig. $2 \mathrm{~A}$, cells from mice transplanted with LPS-r donor cells produced at least $50 \%$ less TNF- $\alpha$ after LPS stimulation than splenocytes obtained from recipients 
Splenocytes

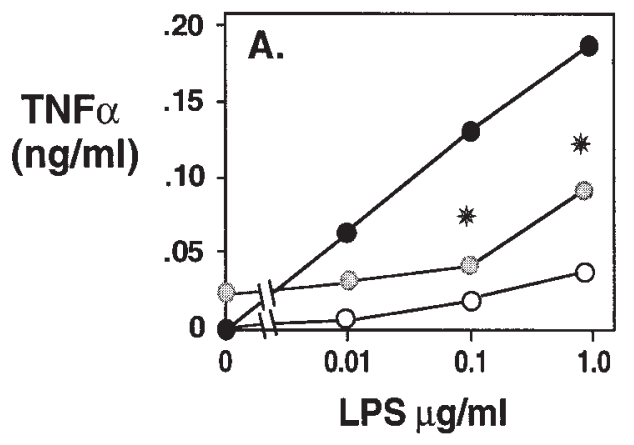

Figure 2. Recipients of LPS-s BMT produce significantly more TNF- $\alpha$ both in vitro $(A)$ and in vivo $(B)$ compared with recipients of LPS-r BMT. (C3FeB6)F1 mice received allogeneic LPS-s BMT (filled circles and bars) or LPS-r BMT (shaded circles and bars) as described in Methods. Negative GVHD controls received TCD LPS-s BM alone (open circles and bars). (A) Day 6 after BMT, splenocytes were harvested from transplanted mice (four per group), pooled, and cultured with increasing concentrations of LPS described in Methods. TNF- $\alpha$ was measured by ELISA. Data are expressed as mean \pm SEM of triplicate wells, shaded vs. filled circles. $* P<0.01$. (B) Day 6 after BMT, mice were bled, and serum was analyzed for TNF- $\alpha$ by ELISA. Data are expressed as mean \pm SEM. Shaded vs. filled bars; $* P<0.01$. (Allogeneic, $n=7$ to eight per group; $\mathrm{TCD}, n=4)$. of LPS-s BMT $(P<0.01)$, although significant amounts of TNF- $\alpha$ were produced compared with naive LPS-r macrophages (Fig. $1 \mathrm{~A}$ ). Since the percentage of macrophages in day +6 spleens was less than that present in naive peritoneal cells ( 22 vs. 33\%), the probable mechanism for this increased sensitivity of LPS-r cells after allogeneic BMT is the large amount of IFN- $\gamma$ produced early during GVHD. IFN- $\gamma$ can prime macrophages for TNF- $\alpha$ production and partially overcome the resistance to LPS in the LPS-r donors (30). The decrease of TNF- $\alpha$ production in vitro correlated well with in vivo results; animals transplanted with LPS-r cells had significantly lower serum TNF- $\alpha$ compared with mice receiving LPS-s BMT (Fig. $2 B, P<0.05)$. TNF- $\alpha$ levels in serum obtained from TCD BMT recipients were 10-15-fold less than either allogeneic BMT group $(P<0.01)$.

Donor resistance to LPS reduces the severity of acute $G V H D$ after allogeneic BMT. Because LPS is a potent stimulus for TNF- $\alpha$, a known inflammatory effector of acute GVHD morbidity and mortality $(4,9,31-33)$, we next evaluated the effects of donor response to LPS on survival and clinical GVHD score after BMT. As shown in Fig. $3 A$, survival in recipients of LPS-r BMT at two T cell doses $\left(1.0\right.$ and $\left.0.25 \times 10^{6}\right)$ was significantly increased compared with mice receiving LPS-s cells
$(P<0.01)$. Surviving animals receiving LPS-r BMT with $0.25 \times$ $10^{6} \mathrm{~T}$ cells were also analyzed weekly for the development of GVHD by using a clinical scoring system described in Methods. Recipients of LPS-r BMT had significantly less severe GVHD at weeks 2, 4, and 5 than mice transplanted with LPS-s donor cells (Fig. $3 B, P<0.01$ ).

Effects of donor responsiveness to LPS on GVHD are independent of donor $T$ cell reactivity to host antigens. Induction of GVHD fundamentally depends on T cell reactivity to host alloantigens (1), and TNF- $\alpha$ has been shown to enhance the activation, expansion, and survival of T cells, both in vivo and in vitro $(34,35)$. It was possible, therefore, that decreased GVHD severity seen after LPS-r BMT could be mediated by diminished donor $\mathrm{T}$ cell alloreactivity despite the equivalent responses of naive LPS-r and LPS-s T cells to host antigens (Fig. 1). We thus examined the effects of donor responsiveness to LPS on T cell responses to host antigens after BMT by evaluating $\mathrm{T}$ cell expansion and IFN- $\gamma$ production in vivo and $\mathrm{T}$ cell proliferation, cytokine production, and CTL activity in vitro. In these experiments, recipients of syngeneic (C3FeB6)F1 BMT served as negative GVHD controls. As shown in Table I, no differences in serum IFN- $\gamma$ levels were observed after LPS-r or LPS-s BMT; however, levels in both groups were significantly
A. Survival

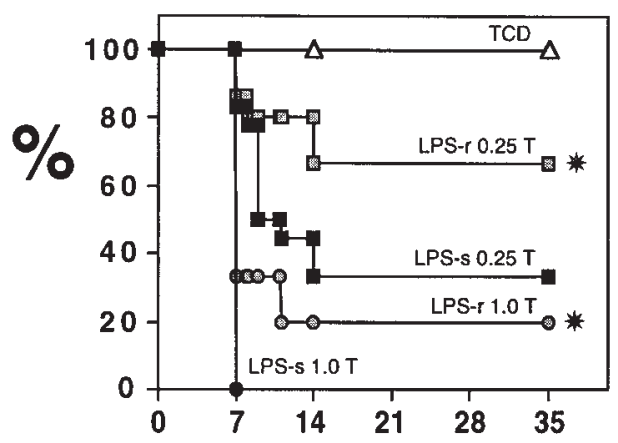

B. Clinical Score

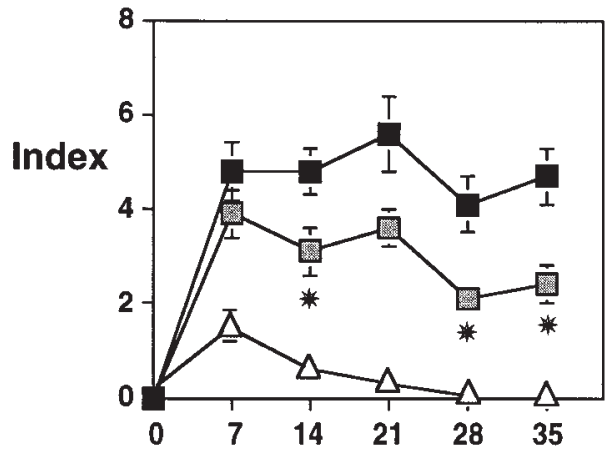

Figure 3. BMT with LPS-r donor cells reduces GVHD related mortality $(A)$ and clinical score $(B)$ after BMT. (C3FeB6)F1 mice received allogeneic LPS-s BMT (filled circle, $1 \times 10^{6} \mathrm{~T}, n=15$; filled squares, $0.25 \times 10^{6} \mathrm{~T}, n=22$ ) or LPS-r BMT (shaded circles, $1 \times 10^{6} \mathrm{~T}, n=20$; shaded squares, $0.25 \times 10^{6} \mathrm{~T}, n=$ 25), and negative GVHD controls received TCD LPS-s BM alone (open triangle, $n=8$ ) as described in Fig. 2. (A) Percent survival at two T cell doses: shaded vs. filled circles; shaded vs. filled squares. Asterisks indicate $P<0.01$ by Wilcoxon

signed rank-test. $(B)$ GVHD score

Day After BMT of surviving animals receiving LPS-s (filled square) and LPS-r (shaded square) BMT with $0.25 \times 10^{6} \mathrm{~T}$ cells or TCD LPS-s BM alone (open triangle): shaded vs. filled squares; ${ }^{*} P<0.01$. T, T cells. Results represent a combination of three separate experiments. 
Table I. Splenic T Cell Expansion and Serum IFN- $\gamma$ Levels Day 6 after BMT

\begin{tabular}{|c|c|c|c|c|}
\hline & \multicolumn{3}{|c|}{ Splenic T cells $\times 10^{6}$} & \multirow[b]{2}{*}{ Serum IFN- -} \\
\hline & $\mathrm{CD}^{+}$ & $\mathrm{CD} 8^{+}$ & Total & \\
\hline \multicolumn{5}{|l|}{ BMT Group } \\
\hline $\begin{array}{l}\text { LPS-s } \rightarrow \mathrm{F} 1 \\
\text { (allogeneic) } n=8 \\
\text { LPS-r } \rightarrow \mathrm{F} 1\end{array}$ & $1.5 \pm 0.5$ & $7.6 \pm 2.5$ & $9.2 \pm 2.6$ & $64.9 \pm 12.1$ \\
\hline $\begin{array}{l}\text { (allogeneic) } n=8 \\
\mathrm{~F} 1 \rightarrow \mathrm{F} 1\end{array}$ & $2.0 \pm 0.4$ & $9.6 \pm 2.8$ & $11.7 \pm 3.1$ & $76.7 \pm 18.7$ \\
\hline (syngeneic) $n=4$ & $0.9 \pm 0.1^{*}$ & $0.3 \pm 0.1^{\ddagger}$ & $1.2 \pm 0.1^{\ddagger}$ & $<0.25^{\ddagger}$ \\
\hline
\end{tabular}

Splenocytes and serum were harvested day 6 after LPS-s and LPS-r BMT and analyzed for T cell surface markers by FACS analysis and IFN- $\gamma$ by ELISA, respectively, as described in Methods. Recipients of syngeneic BMT served as negative GVHD controls. Data are expressed as mean \pm SD. $* P=0.02,{ }^{\ddagger} P=0.01$; syngeneic vs. both allogeneic groups.

higher compared with syngeneic controls $(P<0.01)$. Similarly, no differences in the in vivo expansion of $\mathrm{CD}^{+}$or $\mathrm{CD}^{+}$ splenic $\mathrm{T}$ cell populations were seen between allogeneic BMT groups. Donor T cells from recipients of either LPS-r or LPS-s BMT also showed equal proliferation and IFN- $\gamma$ production when stimulated with host antigens in vitro as shown in Fig. 4 $A$. Similar findings were seen with respect to CTL activity (Fig. $4 B$ ); splenocytes harvested after LPS-r or LPS-s BMT demonstrated equivalent lysis of host type EL-4 (H-2b) tumor targets. The significant lysis of donor type p $210\left(\mathrm{H}-2^{\mathrm{k}}\right)$ tumor targets suggests NK cell activity as previously described during BMT $(5,36)$. Thus, transplantation of cells from LPS-r donors led to a reduction in GVHD despite equivalent donor $\mathrm{T}$ cell reactivity to host antigens both before and after allogeneic BMT. To investigate the relationship between $\mathrm{T}$ cells and accessory cells in the donor graft with respect to GVHD severity, irradiated F1 mice received LPS-s BM together with T cells from either LPS-s or LPS-r donors. A second group received LPS-r BM and either LPS-r or LPS-s T cells. As shown in Table II, recipi-

Table II. Donor Accessory Cell Responsiveness to LPS Predicts GVHD Severity

\begin{tabular}{llcc}
\hline TCD BM & \multicolumn{1}{c}{ T cells } & Survival $(\mathrm{d}+35)$ & Clinical score $(\mathrm{d}+35)$ \\
\hline LPS-s & LPS-s & $2 / 10$ & $7.0 \pm 0.5$ \\
& LPS-r & $2 / 10$ & $6.8 \pm 0.8$ \\
& Total/Average & $4 / 20$ & $6.9 \pm 0.4$ \\
\multirow{3}{*}{ LPS-r } & LPS-s & $5 / 10$ & $4.8 \pm 0.6$ \\
& LPS-r & $5 / 10$ & $3.3 \pm 0.6$ \\
& Total/Average & $10 / 20^{*}$ & $4.1 \pm 0.5^{*}$ \\
\hline
\end{tabular}

(C3F2B6)F1 animals were transplanted as in Fig. 2 and received either TCD LPS-s or LPS-r BM $(n=20)$. Half of each BM group received splenic T cells from LPS-s donors $(n=10)$ and half from LPS-r donors $(n=10)$. Animals were subsequently monitored weekly for survival and clinical score. Recipients of syngeneic BMT $(n=4)$ all survived and showed no evidence of GVHD at day 35 (data not shown). ${ }^{*} P=0.01$, recipients of LPS-r BM vs. LPS-s BM.
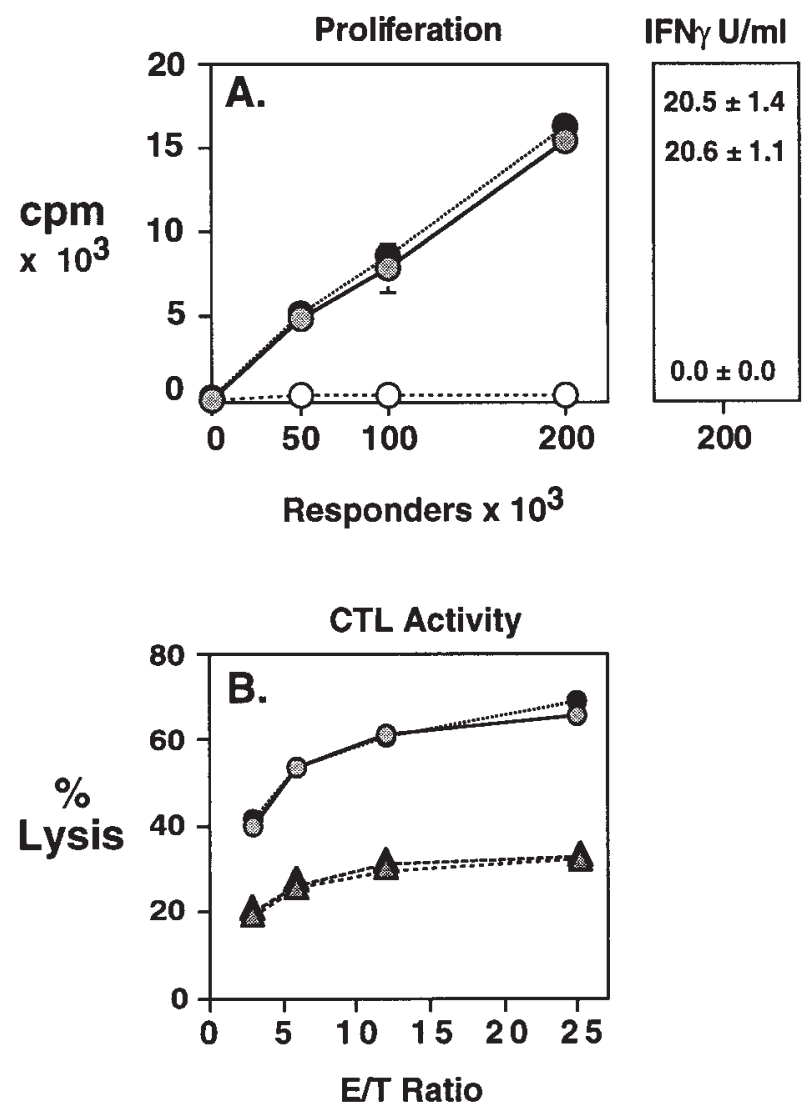

Figure 4. In vitro T cell responses to host antigens $(A)$ and tumor targets $(B)$ are equivalent after LPS-s and LPS-r BMT. (C3FeB6)F1 mice received BMT as in Fig. 2 (filled circle, LPS-s BM + T; shaded circle, LPS-r BM + T; open circle, syngeneic BMT). Splenocytes were harvested $6 \mathrm{~d}$ after BMT from transplanted animals (four per group), pooled, and cultured with irradiated host stimulator cells $(A)$ or tumor targets $(B)$ as described in Methods. $(A)$ Proliferation and IFN- $\gamma$ production of splenic T cells to $(\mathrm{C} 3 \mathrm{FeB} 6) \mathrm{F} 1$ antigens in vitro. Values for proliferation and IFN- $\gamma$ concentration were normalized for the percentage of $\mathrm{T}$ cells present in each group as in Fig. 1. IFN- $\gamma$ levels were measured at maximum proliferative response $\left(200 \times 10^{3}\right.$ responders per well). Data are expressed as mean \pm SEM of triplicate wells and represent one of three similar experiments. $(B)$ CTL responses to host type (circles, EL-4) and donor type (triangles, p210) tumor cell lines by chromium release assay. Data are expressed as mean \pm SEM of quadruplicate wells.

ents of LPS-r BM had increased survival (50 vs. $20 \%$; $P=$ $0.01)$ and less severe systemic GVHD ( $4.1 \pm 0.5$ vs. $6.9 \pm 0.8$; $P<0.01)$ irrespective of donor T cell type. Furthermore, no differences in GVHD severity were seen after transplantation with LPS-r BM and T cells compared with BMT with LPS-r BM, and LPS-s T cells. Taken together, these data demonstrate that the effects of donor responsiveness to LPS on GVHD severity reside in the accessory cell compartment of the donor grafts and are independent of donor $\mathrm{T}$ cell responses to host antigens.

Transplantation of LPS-resistant donor cells results in reduced intestinal injury and decreased serum LPS levels after $B M T$. Having established equivalent donor $\mathrm{T}$ cell responses to host antigens, we next investigated the mechanism by which the donor response to LPS might regulate the severity of 
GVHD. Because TNF- $\alpha$ production to LPS was decreased both in vivo and in vitro, and because TNF- $\alpha$ is known to be an important inflammatory mediator of gastrointestinal (GI) GVHD $(31,37)$, we analyzed whether systemic TNF- $\alpha$ levels correlated with GI pathology after BMT. As shown in Fig. 5, $A$ and $B$, small bowel samples from recipients of TCD BMT demonstrate reestablishment of normal intestinal architecture by day 6 after BMT. Low power microscopy $(\times 200)$ of an $\mathrm{H} \&$ E stained section shows normal appearing intestinal villi and crypts (Fig. 5 A) and higher magnification $(\times 400)$ demonstrates normal epithelial cytology and the absence of cellular infiltrates (Fig. 5 B). By contrast, recipients of LPS-s bone marrow and $\mathrm{T}$ cells developed severe gastrointestinal toxicity.
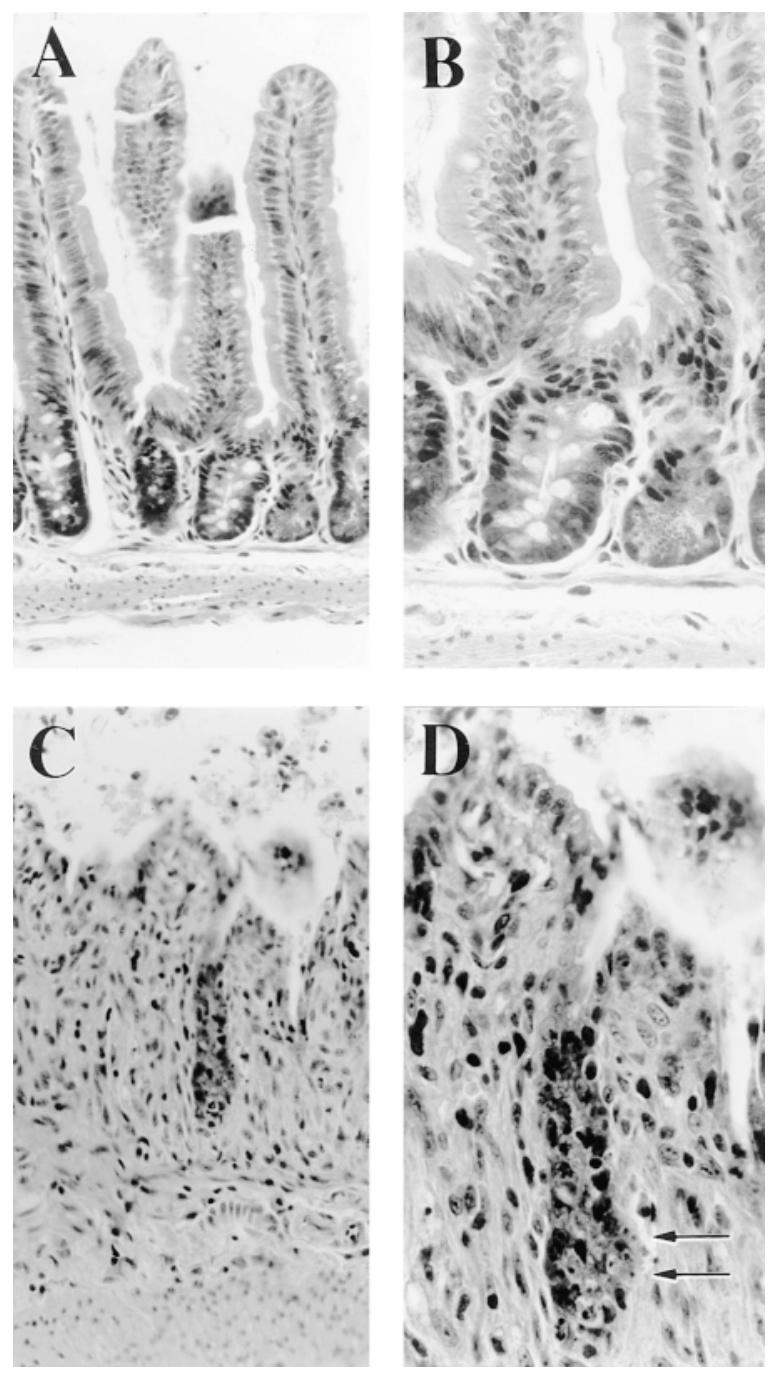

Figure 5. BMT with LPS-s donor cells results in severe GI tract GVHD day 6 after BMT, whereas recipients of TCD BMT demonstrate reestablishment of normal intestinal architecture. Small bowel samples from TCD BMT recipients ( $A$ and $B$ ) show normal appearing villi and crypts $(A)$ and normal epithelial cytology without cellular infiltrates $(B)$. By contrast, recipients of LPS-s BM and T cells developed severe intestinal toxicity including surface erosion, villous blunting, and crypt destruction $(C)$ as well as alterations in epithelial cytology such as an intense cellular infiltration into the lamina propria $(D)$ and single-cell apoptosis (arrows). Original magnification: $(A$ and $B)$ $\times 200 ;(C$ and $D) \times 400$.
This injury involved disruptions of the intestinal architecture including surface erosion, villous blunting, and crypt destruction (Fig. $5 \mathrm{C}$ ) as well as alterations in epithelial cytology such as single-cell apoptosis and an intense cellular infiltration into the lamina propria (Fig. $5 \mathrm{D}$ ). These findings were incorporated into a semiquantitative scoring system as described in Methods. As shown in Fig. 6 A, the mean small bowel pathology index was significantly lower day 6 after BMT in mice transplanted with LPS-r cells compared with animals transplanted with cells from LPS-s donors $(P<0.01)$. Similar differences between groups were also noted in the large bowel (Fig. $6 B, P<0.01)$. Since injury to the intestinal mucosa is critical for the translocation of LPS into the systemic circulation (9), we next measured serum endotoxin levels in these same animals at day 6 after BMT. Recipients of LPS-r BMT had significantly lower serum endotoxin levels compared with animals receiving LPS-s BMT (Fig. $6 C, P=0.02$ ) underscoring the functional consequence of the intestinal damage. Endotoxin was not detected in the serum of animals after TCD BMT consistent with the lack of intestinal pathology observed in these animals. Regression analysis demonstrated a direct correlation of serum LPS levels with small bowel damage (Fig. $6 D, P<$ 0.01 ) as well as large bowel injury (data not shown, $P<0.01$ ). When hepatic injury was evaluated at day 6 after BMT, mean pathology scores did not differ after LPS-s or LPS-r BMT confirming the centrality of GI pathology to overall GVHD severity. Scores were, however, significantly greater in mice receiving allogeneic BMT compared with TCD BMT recipients. (LPS-s $2.3 \pm 0.9$ vs. LPS-r $2.8 \pm 1.5$ vs. TCD $1.0 \pm 0.1, P=0.05$ ).

$T N F-\alpha$ is a significant effector of early intestinal toxicity and GVHD mortality after BMT. To confirm the role of TNF- $\alpha$ in the development of intestinal toxicity and systemic GVHD in this model, we studied the effect of TNF- $\alpha$ neutralization early in the time course of BMT. Recombinant human TNF receptor: $\mathrm{Fc}$ (TNFR:Fc) is a bivalent, soluble form of the TNF- $\alpha$ receptor bound to the heavy portion of human Ig molecule. rhTNFR:Fc was administered to $(\mathrm{C} 3 \mathrm{FeB} 6) \mathrm{F} 1$ at a daily dose of $100 \mu \mathrm{g}$ intraperitoneally on days $-2,-1,0,+1,+2$, and then on alternate days up to and including day 6 . The serum halflife of this agent has been shown to be $>20 \mathrm{~h}$ in mice after intravenous administration permitting alternate day treatment (38). Similarly transplanted mice received human $\operatorname{IgG}$ as a control. We assessed the effects of TNF- $\alpha$ blockade on gut damage, LPS levels, and GVHD mortality after LPS-r BMT with $1 \times 10^{6} \mathrm{~T}$ cells. As shown in Fig. 7, $A$ and $B$, the mean pathology scores in both the small and large bowel were significantly lower in mice receiving TNF- $\alpha$ blockade compared with those generated from similarly transplanted animals receiving control $\operatorname{Ig}(P<0.01)$. This protective effect of rhTNFR:Fc on the intestinal mucosa was associated with a significant decrease in serum LPS levels (Fig. $7 C, P<0.05$ ) and translated into improved survival after BMT with either LPS-r or LPS-s donor cells (Fig. 8, $A$ and $B, P=0.01$ ).

\section{Discussion}

We have examined the effects of donor responsiveness to LPS on the development of acute GVHD in an irradiated $\mathrm{P} \rightarrow \mathrm{F} 1$ murine BMT system. Our data demonstrate that BMT with LPS-r donor cells leads to decreased TNF- $\alpha$ production both in vivo and in vitro (Fig. 2) and ultimately results in a significant reduction in systemic GVHD severity (Fig. 3) despite 

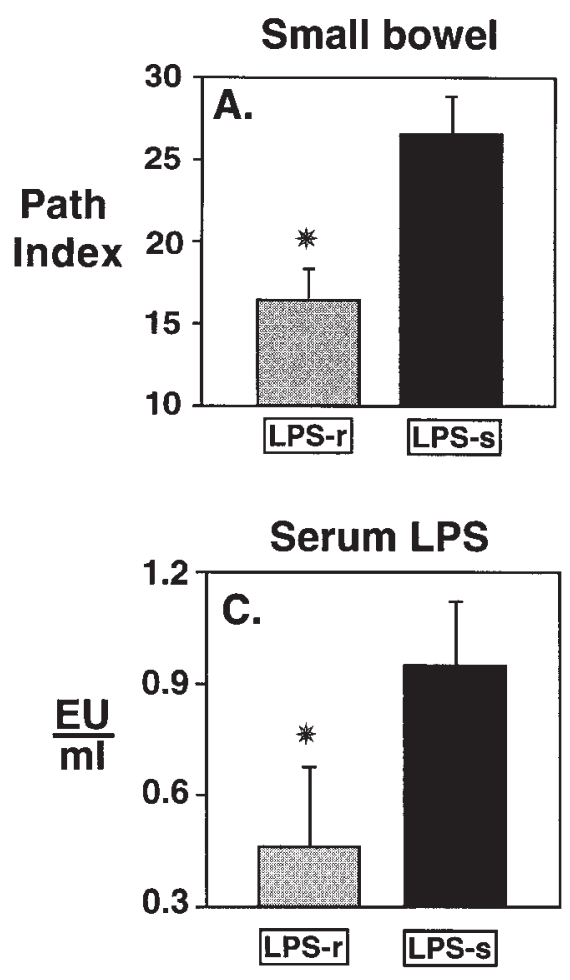
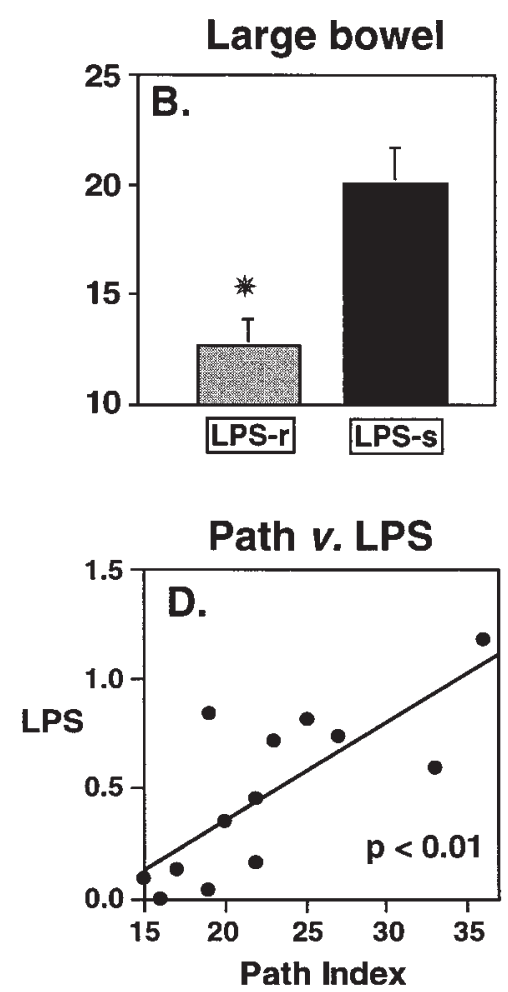

Figure 6. Transplantation of LPS-r donor cells results in decreased intestinal damage $(A$ and $B)$ and serum LPS levels $(C)$ day 6 after BMT. (C3FeB6)F1 mice received BMT with $1 \times 10^{6} \mathrm{~T}$ cells from LPS-s (filled bars) or LPS-r (shaded bars) donors as in Fig. 2. Samples of small $(A)$ and large $(B)$ bowel were harvested from transplanted animals and analyzed using the semiquantitative scoring system described in Methods. Serum was obtained from transplanted animals and analyzed for LPS $(C)$ as described in Methods. Data are expressed as mean \pm SEM. $* P<0.01$. (Gut histopathology, $n=7$ per group; serum LPS, $n=12$ to 14 per group.) (D) Correlation of small bowel histopathology with serum LPS levels after LPS-s $(n=6)$ and LPS-r $(n=7)$ BMT. Data points represent path indices vs. serum LPS levels for individual animals. equal donor $\mathrm{T}$ cell responses to host antigens both before and after LPS-r or LPS-s BMT (Figs. 1 and 4, Table I). Furthermore, recipients of LPS-r BMT demonstrated decreased intestinal histopathology in both the small and large bowel, a finding that translated into significantly reduced systemic levels of LPS (Fig. 6). The results of mixing experiments in which LPS-r $\mathrm{T}$ cells were added to BM from LPS-s donors and vice versa highlighted the importance of donor accessory cells in predicting GVHD severity (Table II). The relationship between LPS, TNF- $\alpha$, and GVHD was confirmed by direct cytokine neutralization; TNF- $\alpha$ blockade early in the time course of LPS-r BMT effectively reduced gut toxicity, serum LPS levels, and GVHD related mortality (Figs. 7 and 8). Taken together, these findings demonstrate that donor responsiveness to LPS regulates the severity acute GVHD. This effect is independent of donor $\mathrm{T}$ cell responses to host antigens and is mediated by TNF- $\alpha$-induced injury of the GI tract.

Acute GVHD is a frequent and severe complication of allogeneic BMT that is dependent upon the ability of donor T cells to recognize and react to antigenic disparities present in an immunocompromised host (39). Accordingly, classic risk factors for GVHD including HLA disparity between donor and host, sex mismatch, and donor parity all are related to the $\mathrm{T}$ cell component of this process $(40,41)$. In this light, a number of in vitro assays have been developed in an effort to predict the likelihood of developing GVHD (42-45). Host-specific CTLs have been identified in patients with acute GVHD, but their presence does not consistently predict GVHD across minor $\mathrm{H}$ antigens (46-48). By contrast, limiting dilution assays of host-specific precursor CTL- and IL-2-producing p HTL frequencies have successfully predicted the incidence and severity of acute GVHD after both HLA-matched sibling and unrelated donor BMT, respectively $(43,49,50)$.

The importance of inflammatory cytokine cascades in the pathogenesis of both clinical and experimental GVHD is now well accepted $(9,32,51-53)$. In particular, TNF- $\alpha$ has been associated with tissue damage resulting from both BMT-conditioning regimens and the development of acute GVHD (32,
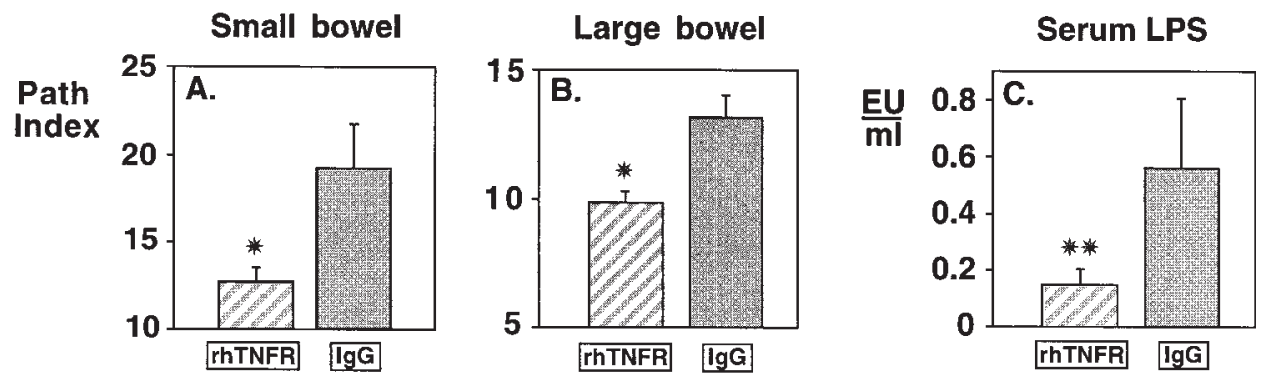

Figure 7. Neutralization of systemic TNF- $\alpha$ from day -2 to day +6 reduces intestinal pathology $(A$ and $B)$ and serum LPS levels $(C)$ day 6 after LPS-r BMT. (C3FeB6)F1 mice received LPS-r BM with $1 \times 10^{6} \mathrm{~T}$ cells and either rhTNFR:Fc (striped bars) or control Ig (shaded bars) as described in Methods. Samples of small bowel $(A)$ and large bowel $(B)$ were harvested from transplanted animals and analyzed using the semiquantitative scoring system as described in Fig. 6. Serum was obtained from transplanted animals and analyzed for LPS as described in Fig. $6(C)$. Data are expressed as mean \pm SEM. $* P<0.02, * * P<0.05$. $(n=8$ to 13 per group $)$. 
A. Survival LPS-r

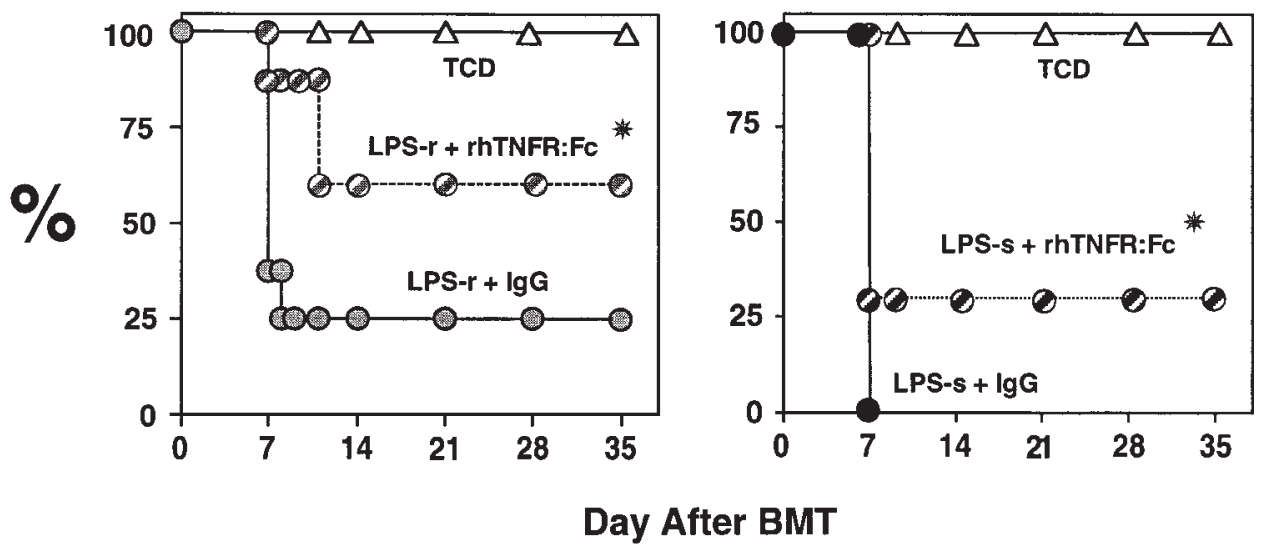

Figure 8. Neutralization of systemic TNF- $\alpha$ from day -2 to day +6 improves survival after LPS-r $(A)$ or LPS-s $(B)$ BMT. ( $A$ ) (C3FeB6)F1 mice received LPS-r BM with $1 \times$ $10^{6} \mathrm{~T}$ cells and either rhTNFR:Fc (striped circles), $n=10$ or control Ig (shaded circles), $n=8$, and $(B)$ (C3FeB6)F1 mice received LPS-s BM with $1 \times 10^{6} \mathrm{~T}$ cells and either rhTNFR:Fc (striped circles), $n=10$ or control Ig (filled circles), $n=8$ as described in Fig. 7. Negative GVHD controls received TCD LPS-s BM alone and control Ig (triangles), $n=$ 4. Striped vs. shaded circles and striped vs. filled circles, $P=0.01$ by Wilcoxon signed rank-test.
33, 53, 54). Holler et al. (55) have demonstrated that hostrelated secretion of TNF- $\alpha$ during pretransplant conditioning correlated with the subsequent development of severe GVHD and mortality after BMT. Analysis of clinical risk factors for enhanced $\mathrm{TNF}-\alpha$ responses suggested a role for endogenous endotoxin and immunogenetic determinants of cytokine activation (55). The gene encoding $\mathrm{TNF}-\alpha$ is located within the MHC locus on chromosome 6 (56), and inducibility of TNF- $\alpha$ has been associated with certain HLA class II genotypes (57) suggesting the existence of inherently high or low TNF- $\alpha$ producers within the general population. Recently, a biallelic polymorphism strongly associated with HLA-DR3 has been identified in the promoter region of the TNF- $\alpha$ gene (the -308 [G/A] polymorphism of an AP-2 transcription factor binding site) with the rare TNF-2 (A) allele correlating with enhanced gene expression (58). When allelic distribution of this polymorphism was analyzed in 72 BMT recipients, a clear association of the TNF-2 (A) allele with enhanced in vitro TNF- $\alpha$ production to LPS and the subsequent development of acute GVHD was noted (59). These reports implicate a role for $\mathrm{TNF}-\alpha$ production by the recipient in predicting the development of GVHD; however, studies investigating inflammatory responses of donor accessory cells in this regard have not been reported. Using mice that differ genetically in their sensitivity to LPS as BMT donors, our data demonstrate for the first time that LPS responsiveness of donor accessory cells can predict GVHD severity and suggest that TNF- $\alpha$ production to LPS simulation by donor cells may be a risk factor for the development of GVHD independent of donor T cell responses to host antigens.

The current findings underscore the role of LPS in the pathogenesis of acute GVHD as suggested by several groups $(4,9,60,61)$. During acute GVHD, gut epithelial damage induced first by the effects of BMT conditioning and subsequently by alloreactive donor T cells allows passage of LPS from the gut lumen into the circulation. Interestingly, endotoxin within the gut lumen can induce local GI epithelial apoptosis after irradiation (62). Macrophages primed by IFN- $\gamma$ produced by activated donor $\mathrm{T}$ cells during GVHD release cytopathic amounts of inflammatory mediators when stimulated by small and normally physiologically insignificant amounts of LPS (4). TNF- $\alpha$ directly damages the gut epithelium $(31,37)$ and increased systemic TNF- $\alpha$ levels may amplify local intestinal injury resulting from activation of gut-associated lymphocytes and macrophages by LPS (63). These inflammatory mechanisms, combined with $\mathrm{T}$ cell and NK cell effectors of allogeneic damage $(5,64,65)$, may perpetuate mucosal damage and the subsequent passage of LPS into the circulation thus establishing a positive feedback loop for progressive target organ injury and dysfunction. Our data demonstrate that a diminished response of donor accessory cells to LPS reduces the development of GVHD by suppressing this feedback loop and attenuating the intestinal toxicity mediated by TNF- $\alpha$.

These results also suggest that methods that modify or prevent early LPS-macrophage interaction may effectively decrease GVHD toxicity after BMT. Several laboratories have demonstrated that maneuvers, which alter the cytokine production by donor cells to host alloantigens, can prevent the enhanced macrophage sensitivity to LPS and the associated mortality that occurs during experimental acute $\operatorname{GVHD}(4,18,66)$. Similarly, agents such as IL-11, which reduce the inflammatory response of activated macrophages to LPS (67), can have beneficial effects when used during allogeneic BMT (68). Data from both experimental and clinical studies examining the effects of gut decontamination on GVHD also support the critical role of LPS to the inflammation of GVHD (69-72). In the clinical setting, gram-negative gut decontamination, a current practice in a large number of transplant centers, has been shown to reduce GVHD $(71,72)$. The magnitude of this effect is small, however, and limited by issues of poor patient compliance and organism resistance to antibiotics; endotoxemia remains common after BMT, even with gut decontamination, and occurs in association with biochemical parameters of gut damage (73). Alternatively, preservation of GI tract integrity by administration of cytokines such as IL-11 early in the time course of allogeneic BMT effectively reduced systemic LPS levels and significantly attenuated GVHD severity in an experimental model (68).

In conclusion, we have found that donor resistance to LPS significantly reduces the severity of acute GVHD after allogeneic BMT and that attenuation of early, TNF- $\alpha-$ mediated, in- 
testinal toxicity is responsible for this effect. Our data suggest that the responsiveness of donor accessory cells to LPS can predict the severity of experimental GVHD and may have at least two potential clinical applications. First, extension of these experimental studies to the clinic could provide functional data, which when combined with other predictors of GVHD, may prove useful in generating a composite GVHD risk score for each BMT donor-recipient pair. Second, novel methods that reduce cellular responses to LPS may be effective adjuncts to standard GVHD prophylaxis. The efficacy of systemic LPS inactivation by neutralizing proteins has been demonstrated in other inflammatory systems (74-77) and should now be studied in GVHD. Experiments are planned that will examine the effects of such soluble LPS antagonists in this system. In either case, the ability to predict and or attenuate inflammatory cytokine profiles during BMT could allow investigators to reduce GVHD by limiting the antigen nonspecific inflammatory component of GVHD without interfering with the antigen-specific response; thus, eventual separation of the beneficial graft-versus-leukemia effect from the toxicities of acute GVHD may be achieved.

\section{Acknowledgments}

We thank Molly Young for her help with statistical analysis

This work was supported by NIH grants HL0356-03, HL55162, and DK39512.

\section{References}

1. Ferrara, J.L.M., and H.J. Deeg. 1991. Graft versus host disease. N. Engl. J. Med. 324:667-674.

2. Sherry, B., and A. Cerami. 1988. Cachectin/tumor necrosis factor exerts endocrine, paracrine and autocrine control of inflammatory responses. J. Cell Biol. 107:1269-1277.

3. D'Andrea, A., M. Rengaraju, N.M. Valiante, J. Chehimi, M. Kubin, M. Aste, S.H. Chan, M. Kobayashi, D. Young, E. Nickborg, et al. 1992. Production of natural killer cell stimulatory factor (interleukin 12) by peripheral blood mononuclear cells. J. Exp. Med. 176:1387-1398.

4. Nestel F.P., K.S. Price, T.A. Seemayer, and W.S. Lapp. 1992. Macrophage priming and lipopolysaccharide-triggered release of tumor necrosis factor alpha during graft-versus-host disease. J. Exp. Med. 175:405-413.

5. McDonald, G.C., and J.G. Gartner. 1992. Prevention of acute lethal graft-versus-host disease in F1 hybrid mice by pretreatment of the graft with anti-NK-1.1 and complement. Transplantation. 54:147-151.

6. Braun, Y.M., B. Lowin, L. French, H. Acha-Orbea, and J. Tschopp. 1996. Cytotoxic T cells deficient in both functional Fas ligand and perforin show residual cytolytic activity yet lose their capacity to induce lethal acute graft-versus-host disease. J. Exp. Med. 183:657-661.

7. Baker, M.B., N.H. Altman, E.R. Podack, and R.B. Levy. 1996. The role of cell-mediated cytotoxicity in acute GVHD after MHC-matched allogeneic bone marrow transplantation in mice. J. Exp. Med. 183:2645-2656.

8. Hill, G.R., W. Krenger, and J.L.M. Ferrara. 1997. The role of cytokines in acute graft-versus-host disease. Cytokines Cell. Mol. Ther. 3:257-265.

9. Hill, G.R., J.M. Crawford, K.R. Cooke, Y.S. Brinson, L. Pan, and J.L.M. Ferrara. 1997. Total body irradiation effects on acute graft versus host disease. The role of gastrointestinal damage and inflammatory cytokines. Blood. 90: 3204-3213.

10. Glode, L.M., and D.L. Rosenstreich. 1976. Genetic control of B cell activation by bacterial lipopolysaccharide is mediated by multiple distinct genes or alleles. J. Immunol. 117:2061-2066.

11. Watson, J., K. Kelly, M. Largen, and B.A. Taylor. 1978. The genetic mapping of a defective LPS response gene in $\mathrm{C} 3 \mathrm{H} / \mathrm{Hej}$ mice. J. Immunol. 120: $422-424$

12. Sultzer, B.M., R. Castagna, J. Bandekar, and P. Wong. 1993. Lipopolysaccharide nonresponder cells: the $\mathrm{C} 3 \mathrm{H} / \mathrm{Hej}$ defect. Immunobiology. 187:257-271

13. Thieblemont, N., and S.D. Wright. 1997. Mice genetically hyporesponsive to lipopolysaccharide (LPS) exhibit a defect in endocytic uptake of LPS and ceramide. J. Exp. Med. 185:2095-2100.

14. Morrison, D.C., and J.L. Ryan. 1979. Bacterial endotoxins and host immune response. Adv. Immunol. 28:294.
15. Tough, D.F., S. Sun, and J. Sprent. 1997. T cell stimulation in vivo by lipopolysaccharide (LPS). J. Exp. Med. 185:2089-2094.

16. Sultzer, B.M., and G.W. Goodman. 1976. Endotoxin protein: a B cell mitogen and polyclonal activator of $\mathrm{C} 3 \mathrm{H} / \mathrm{Hej}$ lymphocytes. J. Exp. Med. 144: 821.

17. Sultzer, B.M. 1983. Lymphocyte activation by endotoxin and endotoxin protein: the role of the $\mathrm{C} 3 \mathrm{H} / \mathrm{Hej}$ mouse. In Beneficial Effects of Endotoxin. A. Nowotny, editor. Plenum Press, New York. 227.

18. Krenger, W., K.M. Snyder, C.H. Byon, G. Falzarano, and J.L.M. Ferrara. 1995. Polarized type 2 alloreactive $\mathrm{CD}^{+}$and $\mathrm{CD}^{+}$donor T cells fail to induce experimental acute graft-versus-host disease. J. Immunol. 155:585-593.

19. Down, J.D., P. Mauch, M. Warhol, S. Neben, and J.L.M. Ferrara. 1992 The effect of donor $\mathrm{T}$ lymphocytes and total-body irradiation on hematopoietic engraftment and pulmonary toxicity following experimental allogeneic bone marrow transplantation. Transplantation. 54:802-808.

20. Cooke, K.R., L. Kobzik, T.R. Martin, J. Brewer, J. Delmonte, J.M. Crawford, and J.L.M. Ferrara. 1996. An experimental model of idiopathic pneumonia syndrome after bone marrow transplantation. I. The roles of minor $\mathrm{H}$ antigens and endotoxin. Blood. 88:3230-3239.

21. Blazar, B.R., P.A. Taylor, D.C. Snover, S.N. Sehgal, and D.A. Vallera. 1993. Murine recipients of fully mismatched donor marrow are protected from lethal graft-versus-host disease by the in vivo administration of rapamycin but develop an autoimmune-like syndrome. J. Immunol. 151:5726-5741.

22. Blazar, B.R., P.A. Taylor, A. Panoskaltsis-Mortari, G.S. Gray, and D.A. Vallera. 1995. Co-blockade of the LFA1:ICAM and CD28/B7 pathways is a highly effective means of preventing acute lethal graft-versus-host disease induced by fully MHC disparate donor grafts. Blood. 83:3815-3825.

23. Fontaine, P., and C. Perreault. 1990. Diagnosis of graft-versus-host disease in mice transplanted across minor histocompatibility barriers. Transplantation. 49:1177-1179.

24. Crawford, J.M. 1997. Graft-versus-host disease of the liver. In GraftVersus-Host Disease, 2nd ed. J.L.M. Ferrara, H.J. Deeg, and S.J. Burakoff, editors. Marcel Dekker, Inc., New York. 315-336.

25. Mowat, A. 1997. Intestinal graft-versus-host disease. In Graft-VersusHost Disease, 2nd ed. J.L.M. Ferrara, H.J. Deeg, and S.J. Burakoff, editors. Marcel Dekker, Inc., New York. 337-384.

26. Snover, D.C., S.A. Weisdorf, N.K. Ramsay, P. McGlave, and J.H. Kersey. 1984. Hepatic graft versus host disease: a study of the predictive value of liver biopsy in diagnosis. Hepatology. 4:123-130.

27. Snover, D.C., S.A. Weisdorf, G.M. Vercellotti, B. Rank, S. Hutton, and P.A. McGlave. 1985. Histopathologic study of gastric and small intestinal graftversus-host disease following allogeneic bone marrow transplantation. Hum. Pathol. 16:387-392.

28. Krenger, W., K.R. Cooke, S.T. Sonis, J. Crawford, R. Simmons, L. Pan, L. Kobzik, J. Delmonte, M. Karandikar, and J.L.M. Ferrara. 1996. Transplantation of polarized type 2 donor $T$ cells reduces mortality caused by experimental graft-versus-host disease. Transplantation. 62:1278-1285.

29. Mohler, K.M, D.S. Torrance, C.A. Smith, R.G. Goodwin, K.E. Stremler, V.P. Fung, H. Madani, and M.B. Widmer. 1993. Soluble tumor necrosis factor (TNF) receptors are effective therapeutic agents in lethal endotoxemia and function simultaneously as both TNF carriers and TNF antagonists. J. Immunol. 151:1548-1561.

30. Galanos, C., and M.A. Freudenberg. 1993. Mechanisms of endotoxin shock and endotoxin hypersensitivity. Immunobiology. 187:346-356.

31. Piguet, P.F., G.E. Grau, B. Allet, and P. Vassalli. 1987. Tumor necrosis factor/cachectin is an effector of skin and gut lesions of the acute phase of graftvs.-host disease. J. Exp. Med. 166:1280-1289.

32. Holler, E., H.H. Kolb, A. Moller, J. Kempeni, S. Lisenfeld, H. Pechumer, W. Lehmacher, G. Ruckdeschel, B. Gleixner, C. Riedner, et al. 1990 Increased serum levels of tumor necrosis factor alpha precede major complications of bone marrow transplantation. Blood. 75:1011-1116.

33. Remberger M., O. Ringden, and L. Markling. 1994. TNF $\alpha$ levels are increased during bone marrow transplantation conditioning in patients who develop acute GVHD. Bone Marrow Transplant. 15:99-104.

34. Vella, A.T., T. Mitchell, B. Groth, P.S. Linsley, J.M. Green, C.B. Thompson, J.W. Kappler, and P. Marrack. 1997. CD28 engagement and proinflammatory cytokines contribute to T cell expansion and long term survival in vivo. $J$. Immunol. 158:4714-4720.

35. Pape, K.A., A. Khoruts, A. Mondino, and M.K. Jenkens. 1997. Inflammatory cytokines enhance the in vivo clonal expansion and differentiation of antigen-activated CD4 $4^{+}$T cells. J. Immunol. 159:591-598.

36. Gartner, J.G., A.C. Merry, and C.I. Smith. 1988. An analysis of pulmonary natural killer cell activity in F1-hybrid mice with acute graft-versus-host reactions. Transplantation. 46:879-886.

37. Hattori, K., T. Hirano, M. Tateno, K. Oshimi, N. Kayagaki, H. Yagita, and K. Okumura. 1997. The synergistic effects of anti-Fas ligand and TNF- $\alpha$ antibody on the prevention of lethal acute graft-versus-host disease in mice. Blood. 90:206a. (Abstr.)

38. Jacobs, C.A., M.P. Beckmann, K. Mohler, C.R. Maliszewski, W.C. Fanslow, and D.H. Lynch. 1992. Pharmacokinetic parameters and biodistribution of soluble cytokine receptors. Int. Rev. Exp. Pathol. 348:123-135.

39. Billingham, R.E. 1966. The biology of graft-versus-host reactions. Har- 
vey Lect. 62:21.

40. Klingemann, H.G., R. Storb, A. Fefer, H.J. Deeg, F.R. Appelbaum, C.D. Buckner, M.A. Cheever, P.D. Greenberg, P.S. Stewart, K.M. Sullivan, et al. 1986. Bone marrow transplantation in patients aged 45 years and older. Blood. 67:770-776.

41. Weisdorf, D., R. Hakke, B. Blazar, W. Miller, P. McGlave, N. Ramsay, J. Kersey, and A. Filipovitch. 1991. Risk factors for acute graft-versus-host disease in histocompatible donor bone marrow transplantation. Transplantation. 51:1197-1203.

42. Johnsen, H.E., L. Bostrom, J. Moller, J.A. Jorgensen, L. Jensen, and O. Ringden. 1992. A study of donor alloreactivity, which may predict acute graftversus-host disease in HLA identical bone marrow transplantation for early leukemia. Scand. J. Immunol. 35:353-360.

43. Theobald, M., T. Nierle, D. Bunjes, R. Arnold, and H. Heimpel. 1992. Host-specific interleukin-2-secreting donor T-cell precursors as predictors of acute graft-versus-host disease in bone marrow transplantation between HLAidentical siblings. N. Eng. J. Med. 327:1613-1617.

44. Sviland, L., A.M. Dickinson, P.J. Carey, A.D.J. Pearson, and S.J. Proctor. 1990. An in vitro predictive test for clinical graft-versus-host disease in allogeneic bone marrow transplant recipients. Bone Marrow Transplant. 5:105-109.

45. van Els, C.A., A. Bakker, A.H. Zwinderman, F.E. Zwaan, J.J van Rood, and E. Goulmy. 1990. Effector mechanisms in graft-versus-host disease in response to minor histocompatibility antigens. II. Evidence of a possible involvement of proliferative T cells. Transplantation. 50:67-71.

46. Niederwieser, D., A. Grassegger, J. Aubock, M. Herold, C. Nachbaur, A. Rosenmayr, A. Gachter, W. Nussbaumer, S. Gaggl, and C. Huber. 1993. Correlation of minor histocompatibility antigens-specific cytotoxic $\mathrm{T}$ lymphocytes with graft-versus-host disease status and analysis of tissue distribution of their target antigens. Blood. 81:2200-2208.

47. Chao, N.J. 1994. Clinical aspects of graft-versus-host disease. In Medical Intelligence Unit: Graft-Versus-Host Disease. R.G. Landes Company, Austin, TX. 68-84.

48. van Els, C.A., A. Bakker, A.H. Zwinderman, F.E. Zwaan, J.J. van Rood, and E. Goulmy. 1990. Effector mechanisms in graft-versus-host disease in response to minor histocompatibility antigens. I. Absence of correlation with cytotoxic effector cells. Transplantation. 50:62-66.

49. Theobald, M., D. Bunjes, T. Nierle, R. Arnold, and H. Heimpel. 1993. Measurement of recipient-specific alloreactivity: is GVHD predictable? Bone Marrow Transplant. 12(Suppl.):S18-23.

50. Kaminski, E., J. Hows, S. Man, P. Brookes, S. Mackinnon, T. Hughes, O. Avakian, J.M. Goldman, and J.R. Batchelor. 1989. Prediction of graft versus host disease by frequency analysis of cytotoxic $\mathrm{T}$ cells after unrelated donor bone marrow transplantation. Transplantation. 48:608-613.

51. Xun, C.Q., J.S. Thompson, C.D. Jennings, S.A. Brown, and M.B. Widmer. 1994. Effect of total body irradiation, busulfan-cyclophosphamide, or cyclophosphamide conditioning on inflammatory cytokine release and development of acute and chronic graft-versus-host disease in $\mathrm{H}-2$ incompatible transplanted SCID mice. Blood. 83:2360-2367.

52. Antin, J., and J.L.M. Ferrara. 1992. Cytokine dysregulation and acute graft-versus-host disease. Blood. 80:2964-2968.

53. Schwaighofer, H., N.A. Kernan, R.J. O'Reilly, J. Brankova, D. Nachbaur, M. Herold, B. Eibl, and D. Niederwieser. 1996. Serum levels of cytokines and secondary messages after T-cell-depleted and non-T-cell-depleted bone marrow transplantation. Transplantation. 62:947-953.

54. Holler, E., H.J. Kolb, J. Mittermuller, M. Kaul, G. Ledderose, Th. Duell, B. Seeber, M. Schleuning, R. Hintermeier-knabe, B. Ertl, et al. 1995. Modulation of acute graft-versus-host disease after allogeneic bone marrow transplantation by tumor necrosis factor $\alpha(\mathrm{TNF} \alpha)$ release in the course of pretransplant conditioning: role of conditioning regimens and prophylactic application of a monoclonal antibody neutralizing human TNFo (MAK 195F). Blood. 86:890-899.

55. Holler, E., B. Ertl, R. Hintermeier-Knabe, M.G. Roncarolo, G. Eissner, F. Mayer, P. Fraunberger, U. Behrends, W. Pfannes, H.J. Kolb, et al. 1997. Inflammatory reactions induced by pretransplant conditioning-an alternative target for modulation of acute GVHD and complications following allogeneic bone marrow transplantation? Leuk. Lymphoma. 25:217-224.

56. Carroll, M.C., P. Katzman, E.M. Alicot, B.H. Koller, D.E. Geraghty, H.T. Orr, and J.L. Strominger. 1987. Linkage map of the human major histocompatibility complex including the tumor necrosis factor genes. Proc. Natl. Acad. Sci. USA. 84:8535-8539.

57. Jacob, C.O., Z. Fronek, G.D. Lewis, M. Koo, J.A. Hansen, and H.O. McDevitt. 1990. Heritable major histocompatibility complex class II-associated differences in production of tumor necrosis factor $\alpha$ relevance to genetic predisposition to systemic lupus erythematosus. Proc. Natl. Acad. Sci. USA. 87:12331237.

58. Abraham, L.J., M.A. French, and R.L Dawkins. 1993. Polymorphic MHC ancestral haplotypes affect the activity of tumor necrosis factor alpha. Clin. Exp. Immunol. 92:14-18.

59. Mayer, F.R., G. Messer, W. Knabe, W. Mempel, M. Meurer, H.J. Kolb, and E. Holler. 1996. High response of TNF $\alpha$ secretion in vivo in patients undergoing BMT may be associated with the -308 bp TNF- $\alpha$-gene enhancer-polymorphism. Bone Marrow Transplant. 17:s101. (Abstr.)

60. Price, K.S., F.P. Nestel, and W.S. Lapp. 1997. Progressive accumulation of bacterial lipopolysaccharide in vivo during murine acute graft-versus-host disease. Scand. J. Immunol. 45:294-300.

61. Seemayer, T.A., F.P. Nestel, K. Kichian, K.E. You-Ten, J. Desbarats, K Price, P. Ponka, and W.S. Lapp. The role of endotoxin in the pathogenesis of acute graft-versus-host disease. In Graft-Versus-Host Disease, 2nd ed. J.L.M Ferrara, H.J. Deeg, and S.J. Burakoff, editors. Marcel Dekker, Inc., New York. $502-523$.

62. Eissner, G., F. Kohlhuber, M. Grell, M. Ueffing, P. Scheurich, A. Hieke G. Multhoff, G.W. Bornkamm, and E. Holler. 1995. Critical involvement of transmembrane tumor necrosis factor-alpha in endothelial programmed cell death mediated by ionizing radiation and bacterial endotoxin. Blood. 86:4184-4193.

63. Remick, D.G. Lung and gut injury induced by tumor necrosis factor. 1993. Res. Immunol. 144:326-331.

64. Ghayur, T., T. Seemayer, and W.S. Lapp. 1990. Histologic correlates of immune functional deficits in graft-vs.-host disease. In Graft-vs.-Host Disease: Immunology, Pathophysiology, and Treatment. S.J. Burakoff, H.J. Deeg, J. Ferrara, and K. Atkinson, editors. New York: Marcel Dekker, Inc. 109-132.

65. Lin, T., T. Brunner, B. Tietz, J. Madsen, E. Bonfoco, M. Reaves, M. Huflejt, and D.R. Green. 1998. Fas ligand-mediated killing by intestinal intraepithelial lymphocytes-participation in intestinal graft-versus-host disease. $J$. Clin. Invest. 101:570-577.

66. Fowler, D.H., K. Kurasawa, A. Husebekk, P.A. Cohen, and R.E. Gress 1994. Cells of the Th2 cytokine phenotype prevent LPS-induced lethality during murine graft-versus-host reaction. J. Immunol. 152:1004-1013.

67. Trepicchio, W.L., L. Wang, M. Bozza, and A.J. Dorner. 1997. IL-11 regulates macrophage effector function through the inhibition of nuclear factorкB. J. Immunol. 159:5661-5670.

68. Hill, G.R., K.R. Cooke, J.M. Crawford, J.C. Keith, Jr., Y.S. Brinson, D. Bungard, and J.L.M. Ferrara. 1998. Interleukin-11 promotes Th2 polarization and prevents acute graft-versus-host disease after allogeneic bone marrow transplantation. J. Clin. Invest. 102:115-123.

69. van Bekkum, D.W., J. Roodenburg, P.J. Heidt, and D. van der Waaij. 1974. Mitigation of secondary disease of allogeneic mouse radiation chimeras by modification of the intestinal microflora. J. Natl. Cancer Inst. 52:401-404.

70. van Bekkum, D.W., and S. Knaan. 1977. Role of bacterial microflora in development of intestinal lesions from graft versus host disease. J. Natl. Cancer Inst. 58:787-790.

71. Moller, J., P. Skirhoj, N. Hoiby, and F.B. Peterson. 1982. Protection against graft versus host disease by gut sterilization? Exp. Hematol. 10:101-103.

72. Storb, R., R.L. Prentice, C.D. Buckner, R.A. Clift, F. Appelbaum, J. Deeg, K. Doney, J.A. Hansen, M. Mason, J.E. Sanders, et al. 1983. Graft-versus-host disease and survival in patients with aplastic anemia treated by marrow grafts from HLA-identical siblings. Beneficial effect of a protective environment. N. Engl. J. Med. 308:302-307.

73. Jackson, S.K., J. Parton, R.A. Barnes, C.H. Poynton, and C. Fegan. 1993. Effect of IgM-enriched intravenous immunoglobulin (pentaglobulin) on endotoxemia and anti-endotoxin antibodies in bone marrow transplantation. Eur. J. Clin. Invest. 23:540-545.

74. Haziot, A., G.W. Rong, X.Y. Lin, J. Silver, and S.M. Goyert. 1995. Recombinant soluble CD14 prevents mortality in mice treated with endotoxin (lipopolysaccharide). J. Immunol. 154:6529-6532.

75. Christ, W.J., O. Asano, A.L.C. Robidoux, M. Perez, Y. Wang, G.R. Dubuc, W.E. Gavin, L.D. Hawkins, P.D. McGuinness, M.A. Mullarkey, et al. 1995. E5531, a pure endotoxin antagonist of high potency. Science. 268:80-83.

76. Leturcq, D.J., A.M. Moriarty, G. Talbott, R.K. Winn, T.R. Martin, R.J. Ulevitch. 1996. Antibodies against CD14 protect primates from endotoxininduced shock. J. Clin. Invest. 98:1533-1538.

77. Lamping, N., R. Dettmer, N.W.J. Schroder, D. Pfeil, W. Hallatschek, R. Burger and R.R. Schumann. 1998. LPS-binding protein protects mice from septic shock caused by LPS or gram-negative bacteria. J. Clin. Invest. 101:20652071. 